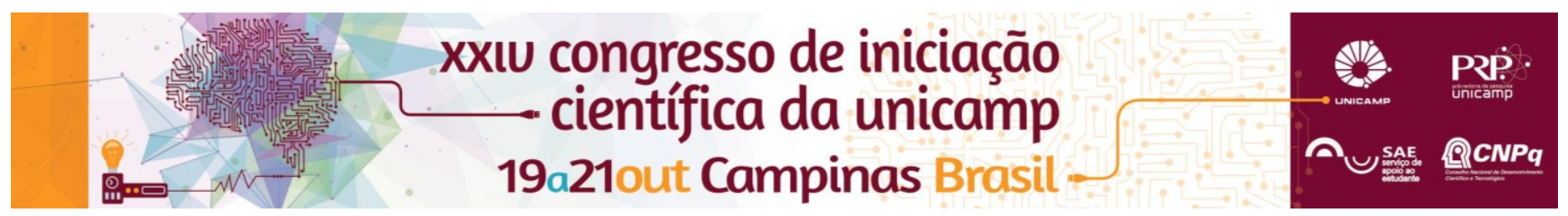

\title{
O corpo que dança com os orixás: pesquisa corporal no eixo Co-habitar com a Fonte do método BPI a partir de pesquisa de campo em terreiros de Candomblé
}

\author{
Jaqueline Soraia Rossi (IC) \\ Larissa Sato Turtelli (Orientadora)
}

\section{Resumo}

Esta pesquisa teve como objetivo realizar uma investigação corporal no eixo Co-habitar com a Fonte do método BPI (Bailarino-Pesquisador-Intérprete) a partir de pesquisa de campo com foco nas movimentações e sentidos das danças dos orixás presentes em rituais públicos de terreiros de Candomblé da cidade de Campinas-SP. Concomitantemente às pesquisas de campo foram realizados os laboratórios dirigidos do método BPI para investigar o que a pesquisa de campo mobilizaria no corpo da pesquisadora. Inicialmente foram pesquisados rituais em cinco terreiros de Candomblé e em uma segunda etapa foi selecionado um deles para ser o foco da pesquisa. O campo permitiu o contato com as danças de diversos orixás, o aprendizado da pesquisadora em não ter uma postura etnocêntrica, bem como um abundante fluxo de movimentos, sensações, imagens e sentimentos nos laboratórios dirigidos.

\section{Palavras-chave:}

Dança do Brasil, Método BPI (Bailarino-Pesquisador-Intérprete), Pesquisa de Campo

\section{Introdução}

Os terreiros de Candomblé trazem uma requintada movimentação corporal, envolvendo tanto as danças dos orixás, quanto os diversos cumprimentos e outros gestos ritualísticos. Foi nas disciplinas de Dança do Brasil do Curso de Graduação em Dança da Unicamp que a pesquisadora percebeu sua identificação corporal com esse universo, a qual pôde ser constatada nos laboratórios dirigidos do método BPI (Bailarino-Pesquisador-Intérprete) vivenciados nas disciplinas de Dança do Brasil.

A partir dessa identificação esse projeto teve como objetivo realizar uma investigação corporal embasada na pesquisa de campo com foco nas movimentações e sentidos das danças dos orixás presentes em rituais públicos de terreiros de Candomblé da cidade de Campinas-SP. A pesquisa foi fundamentada no eixo Cohabitar com a Fonte do método BPI, do qual fazem parte as pesquisas de campo e os laboratórios dirigidos, nos quais são investigadas as repercussões do trabalho de campo no corpo da pesquisadora (Rodrigues, 2003).

\section{Resultados e Discussão}

Foram empreendidas pesquisas de campo em cinco terreiros de Candomblé e escolhido um deles para o foco da pesquisa. Ao todo foram realizadas 13 idas a campo, nas quais foram presenciadas danças de diferentes orixás e entidades, como Ogun, Ibejis, Oiá, Xangô, Oxossi, Oxum, Pretos Velho e Caboclos.

Através da Estrutura Física e da Anatomia Simbólica do método BPI foram estudadas as movimentações desses orixás incorporados em seus filhos-de-santo. Destacou-se a força dessas danças e o quanto elas modificavam os corpos dos filhos de santo, ou seja, havia mudanças no tônus muscular, postura, atitude e expansão potencializados em corpos fora dos padrões habituais da dança ocidental "de palco".
Nos laboratórios dirigidos surgiram no corpo da pesquisadora conteúdos variados e aparentemente distintos entre si. Foram várias modelagens corporais, ocorreram fluxos de imagens, movimentos e sensações, dando vazão a sentimentos presentes no corpo da pesquisadora, remetendo tanto à pesquisa de campo quanto à sua história pessoal.

\section{Conclusões}

A pesquisa de campo possibilitou o contato com conflitos pessoais e empatias da pesquisadora, permitindo quebrar idealizações, trazendo uma outra visão da força de vontade e dedicação dos filhos de santo. A relação com esse campo - o qual foi buscado pela pesquisadora devido a uma identificação corporal com um corpo presente e ativo, propiciou a intensificação de modelagens com fluxos de movimentos, sensações e imagens durante os laboratórios dirigidos. Percebeu-se o quanto inúmeros conteúdos - antes desconhecidos podem ser descobertos no próprio corpo, provendo um dinamismo corporal criativo.

\section{Agradecimentos}

À Larissa Sato Turtelli pela atenção e orientação, à FAPESP (Fundação de Amparo à Pesquisa do Estado de São Paulo) pelo financiamento da bolsa, ao Grupo de Pesquisa BPI e Dança do Brasil pela generosidade e companheirismo e a todo o povo de santo pela sabedoria e abertura.

RODRIGUES, G.E.F. O Método BPI (Bailarino-Pesquisador-Intérprete) e o desenvolvimento da imagem corporal: reflexões que consideram o discurso de bailarinas que vivenciaram um processo criativo baseado neste método. 2003 171p. Tese (Doutorado em Artes) - Instituto de Artes, Universidade Estadual de Campinas, Campinas, 2003. 